\title{
Slik håndterer \\ sykepleiere og brukere vond lukt i hjemmet
}

\section{Grete Breievne}

Førsteamanuensis

VID vitenskapelige høgskole, Oslo

\section{Kristin Margrete Heggen}

Professor

Seksjon for ledelse, Universitetet i Oslo

\section{Hilde Bondevik}

Professor

Avdeling for helsefag, Det medisinske fakultet, Universitetet i Oslo

Hjemmesykepleie

Kvalitativ studie

Sykepleier-pasient-forhold**

Sykepleien Forskning 201813 (65987) (e-65987)

DOI: 10.4220/Sykepleienf.2018.65987

\section{Sammendrag}

Bakgrunn: Ubehagelig lukt i hjemmet eller fra en person er sosialt uakseptabelt og skambelagt. Hvordan hjemmesykepleiere erfarer og håndterer ubehagelig lukt i samhandling med brukere, og hvordan brukerne opplever sykepleierens handlingsvalg, er per i dag et lite utforsket område.

Hensikt: Hensikten med studien er å unders $\varnothing$ ke hvordan sykepleiere erfarer og håndterer luktproblematikk i hjemmet, og hvordan brukere opplever og vurderer sykepleiernes handlingsvalg.

Metode: Vi foretok en kvalitativ studie med observasjon og intervju av 30 sykepleiere og 11 pasienter i 3 hjemmesykepleiedistrikter i en større norsk by. 
Resultat: Ubehagelig lukt i hjemmene var oftest forårsaket av sykdom og sviktende hygiene hos brukerne. Sykepleierne oppfattet lukt i hjemmet som skambelagt. De oppfattet brukerne som dobbelt sårbare fordi både person og hjem var utsatt for andres avsky. De ønsket å beskytte brukerne mot skammen. De vanligste handlingsstrategiene var å fjerne lukt gjennom praktisk handling, unngå å vise kroppslige reaksjoner på lukt og forholde seg tause om luktproblematikk. Brukerne opplevde at luktfjerning gjennom praktisk handling var viktig for sosial trygghet. Taushet forsterket skammen og ensomheten og bidro i noen tilfeller til et svekket behandlingstilbud. Brukerne $\varnothing$ nsket st $\varnothing$ rre åpenhet.

Konklusjon: Det er behov for større åpenhet og fagkunnskap om luktproblematikk i hjemmet. Det er viktig å etterspørre brukernes erfaringer og $\emptyset n s k e r$ for å utvikle et adekvat pleie- og behandlingstilbud.

Hjemmesykepleiere må ofte forholde seg til ubehagelige lukter, både fra omgivelsene og på grunn av sykdom. Å lukte vondt eller omgi seg med ubehagelige lukter som sjenerer andre, blir gjerne oppfattet som sosialt uakseptabelt. Det medfører gjerne lidelse hos pasienter i form av frykt for andres $\operatorname{avsky~(1-8).~}$

Samtidig er det krevende for sykepleiere å være i pasientsituasjoner som involverer vond lukt. Luktene skaper kroppslige reaksjoner som grimaser, kvalme og $\varnothing$ nske om å fjerne seg fra situasjonen $(6,9,10)$. Vond lukt er også et vanskelig tema å snakke om med brukere (11).

Undersøkelsene vi viser til her, er gjennomført på sykehus eller annen institusjon. Det er begrenset forskning på hvordan sykepleiere erfarer og håndterer luktutfordringer i relasjon med brukere i hjemmet. Likedan er det få beskrivelser av brukernes erfaringer med og vurderinger av sykepleierens håndtering av lukt i denne konteksten, og hvordan brukerne ønsker å bli møtt (12).

Hensikten med denne artikkelen er å utforske luktproblematikk i hjemmet med utgangspunkt i følgende spørsmål: 
- Hvilke lukter møter sykepleiere i hjemmet?

- Hvordan erfarer og håndterer sykepleierne ubehagelig lukt i hjemmet i relasjon med brukerne?

- Hvordan erfarer og vurderer brukerne sykepleierens handlingsvalg?

Artikkelen er en delstudie i en st $\varnothing$ rre studie, der hensikten var å utvikle kunnskap om hvordan luktproblematikk i hjemmesykepleien håndteres overfor brukere, og hvordan problematikken håndteres som et faglig tema på arbeidsstedene (12).

\section{Metode og analysestrategi}

Vi benyttet et etnografisk design, der et sentralt anliggende er å beskrive hva mennesker sier og gjør i situasjoner som ikke fullt ut er strukturert av forskeren (13). Feltene i den empiriske unders $\varnothing$ kelsen omfattet tre hjemmesykepleiedistrikter og en privat tilbyder i en større norsk by, som fokuserte på palliativ omsorg $\mathrm{i}$ hjemmet.

Utvalget av informanter var strategisk. 30 sykepleiere og 11 brukere deltok. Vi rekrutterte sykepleierne etter informasjonsmøter i de valgte feltene. Inklusjonskriteriene var minst to års yrkeserfaring der luktproblematikk inngikk. Informantene måtte dessuten beherske norsk muntlig og skriftlig. Brukerne ble rekruttert ved forespørsel fra sykepleierne.

Inklusjonskriteriene for brukerne var at de skulle være over 20 år og ha hatt en lidelse som medførte luktproblematikk i minst ett år. De måtte forstå norsk muntlig og skriftlig samt være samtykkekompetente.

Vi benyttet deltakende observasjon og semistrukturert intervju som metoder. Observasjonene og intervjuene foregikk i tidsrommet høsten 2009 til våren 2011. Førsteforfatteren hadde hovedansvaret for datainnsamlingen og analysen, men i nær dialog med medforfatterne. 


\section{Observasjon}

Observasjonsmaterialet omfattet ni observasjoner i pleiesituasjoner i hjemmet til brukerne. Vi utformet observasjonsguiden med henblikk på å få frem hvordan sykepleiere håndterte luktutfordringer i samhandling med brukere. Førsteforfatteren utformet feltnotater, som omfattet nøyaktige situasjonsbeskrivelser. De inneholdt også refleksjoner over egne reaksjoner og metodiske og etiske spørsmål.

Intervjumaterialet fra sykepleierne omfattet seks fokusgruppeintervjuer og sju individuelle intervjuer etter observasjon av sykepleiernes samhandling med brukerne i hjemmet.

\section{Intervjuer}

Fokusgruppeintervjuene varte mellom 45 og 75 minutter, mens intervjuene etter observasjon varte mellom 15 og 25 minutter. Alle intervjuene foregikk i hjemmesykepleiens lokaler. Vi utformet intervjuguiden for sykepleierne med tanke på å få frem deres lukterfaringer i hjemmet, handlingsvalg og begrunnelser.

Brukerintervjuene var individuelle og omfattet sju kvinner og fire menn i alderen 35-85 år med langvarig luktproblematikk fra sår, infeksjoner og stomier. Kreft var bakenforliggende diagnose hos fire av informantene. Intervjuene foregikk i brukernes hjem og varte mellom 15 og 55 minutter. Vi utformet intervjuguiden for brukerne med henblikk på å få frem deres erfaringer og $\varnothing$ nsker rundt sykepleierens håndtering av luktproblematikk.

\section{Analyse}


Alle intervjuene ble tatt opp på bånd og transkribert. I analysen benyttet vi en aktørorientert tilnærming med utgangspunkt i informantenes utsagn og forskerens observasjoner. Idealet er her å utvikle erfaringsnære begreper som gjenspeiler informantenes perspektiver (13) (tabell 1). I tråd med anbefalinger av studier som omfatter ulike informantgrupper, foretok vi først

separate analyser av gruppene før resultatene ble satt sammen (14).

Tabell 1: Eksempel på utvikling av erfaringsnære begreper med utgangspunkt i spørsmålet: «Hvordan håndterer sykepleiere ubehagelig lukt i møte med brukere?»

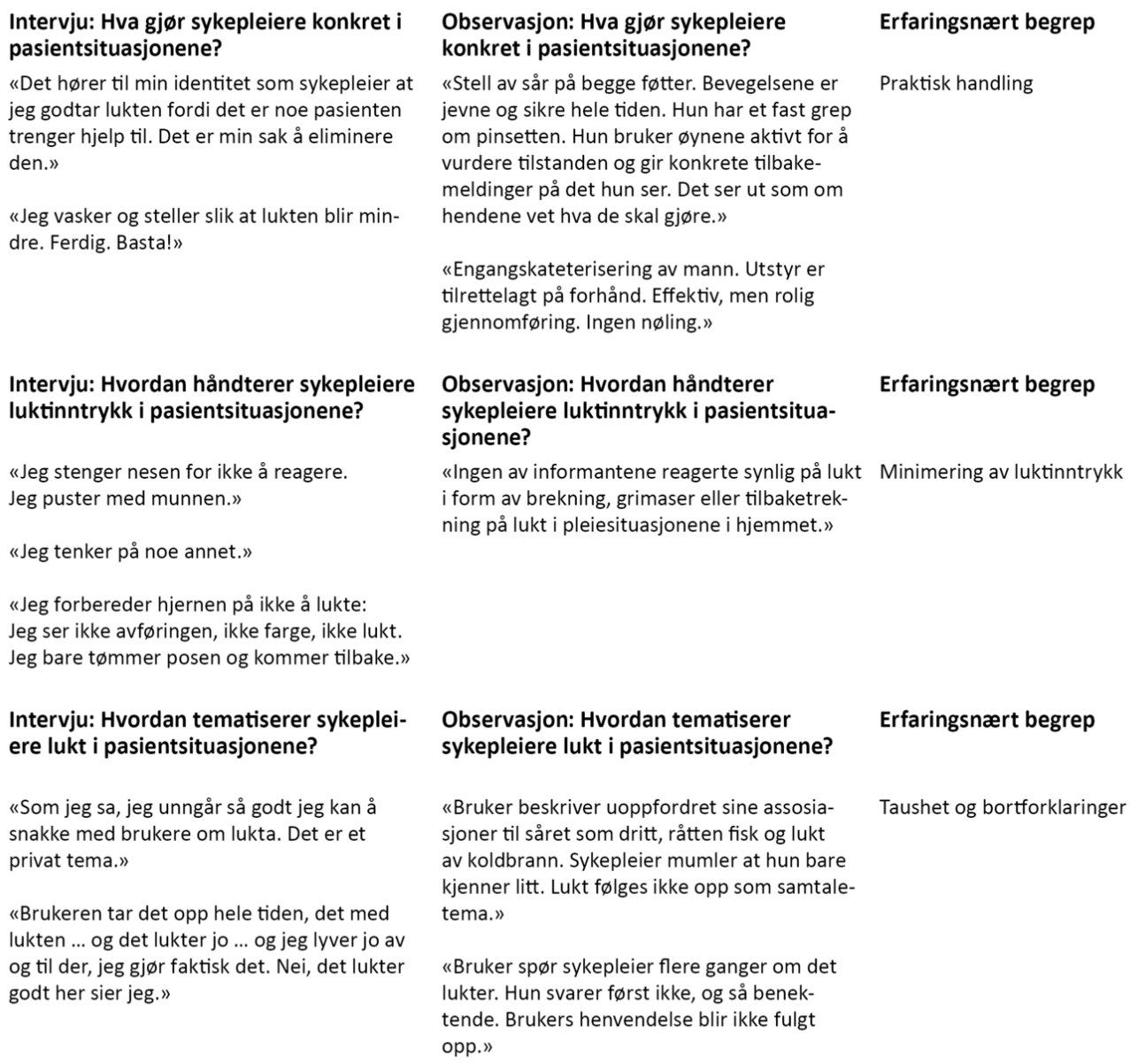

Observasjon: Hva gjør sykepleiere konkret i pasientsituasjonene?

«Det hører til min identitet som sykepleier at jeg godtar lukten fordi det er noe pasienten trenger hjelp til. Det er min sak å eliminere den.»

"Jeg vasker og steller slik at lukten blir mindre. Ferdig. Basta!»

Intervju: Hvordan håndterer sykepleiere luktinntrykk i pasientsituasjonene?

«Jeg stenger nesen for ikke å reagere. Jeg puster med munnen.»

«Jeg tenker på noe annet.»

«Jeg forbereder hjernen på ikke å lukte: Jeg ser ikke avføringen, ikke farge, ikke lukt. Jeg bare tømmer posen og kommer tilbake.»

Intervju: Hvordan tematiserer sykepleiere lukt i pasientsituasjonene?

«Som jeg sa, jeg unngår så godt jeg kan å snakke med brukere om lukta. Det er et privat tema.»

«Brukeren tar det opp hele tiden, det med lukten ... og det lukter jo ... og jeg lyver jo av og til der, jeg gjør faktisk det. Nei, det lukter godt her sier jeg.»

"Stell av sår på begge føtter. Bevegelsene er jevne og sikre hele tiden. Hun har et fast grep om pinsetten. Hun bruker øynene aktivt for å vurdere tilstanden og gir konkrete tilbakemeldinger på det hun ser. Det ser ut som om hendene vet hva de skal gjøre.»

«Engangskateterisering av mann. Utstyr er tilrettelagt på forhånd. Effektiv, men rolig gjennomføring. Ingen nøling.»

Observasjon: Hvordan håndterer sykepleiere luktinntrykk i pasientsituasjonene?

«Ingen av informantene reagerte synlig på lukt Minimering av luktinntrykk i form av brekning, grimaser eller tilbaketrekning på lukt i pleiesituasjonene i hjemmet.»

Observasjon: Hvordan tematiserer sykepleiere lukt i pasientsituasjonene?

«Bruker beskriver uoppfordret sine assosiasjoner til såret som dritt, råtten fisk og lukt av koldbrann. Sykepleier mumler at hun bare kjenner litt. Lukt følges ikke opp som samtaletema.»

«Bruker spør sykepleier flere ganger om det lukter. Hun svarer først ikke, og så benektende. Brukers henvendelse blir ikke fulgt opp.»

\section{Erfaringsnært begrep}

Praktisk handling

Erfaringsnært begrep

Erfaringsnært begrep

Taushet og bortforklaringer 
Vi startet med en tverrgående analyse av feltnotater og intervjuer med sykepleiere om hvilke lukter de møtte i hjemmene, og hvordan de erfarte disse. Deretter så vi på hvordan sykepleierne håndterte erfaringene $\mathrm{i}$ samhandling med brukere, og hvordan de begrunnet handlingsvalgene. Informantenes svar reflekterte både nåværende og tidligere erfaring. Vi sammenfattet svarene i tekstsammendrag med oppmerksomhet på kjernepunkter, forskjeller, likheter og påvirkende faktorer.

Vi foretok deretter en tverrgående analyse av brukerintervjuene om hvordan de opplevde at luktproblematikken hadde blitt håndtert, og hva de kunne ønske seg annerledes. Svarene ble sammenfattet i tekstsammendrag med oppmerksomhet på kjernepunkter, forskjeller og likheter. Videre sammenliknet vi brukernes erfaringer, refleksjoner og $\varnothing$ nsker med sykepleiernes handlingsstrategier.

Vi diskuterte funnene i lys av sosiokulturelle og sykepleiefaglige perspektiver på hvordan tabu- og skambelagte problemstillinger håndteres $i$ en vestlig kulturtradisjon.

\section{Godkjenning og samtykke}

Prosjektet ble meldt til Norsk senter for forskningsdata (NSD) og godkjent av Regionale komiteer for medisinsk og helsefaglig forskningsetikk (REK) (søknadsnummer S-o9148d, 2009/1953).

Vi innhentet skriftlig informert samtykke fra sykepleier- og brukerinformantene. A lukte vondt er tabubelagt og stiller forskningsetiske krav til å ivareta informantenes integritet. Da vi forespurte deltakerne om å være med i studien, fikk de et informasjonsskriv som synliggjorde hvor sykepleierne og brukerne kunne henvende seg dersom de opplevde at deltakelsen var en belastning. Vi fikk ingen slike henvendelser. 


\section{Resultater}

\section{Sykepleiernes erfaringer og handlingsvalg}

\section{Lukt i hjemmet}

Hjemmets lukter kunne være forårsaket av enkeltstående, gjennomtrengende sykdomslukter, som for eksempel lukten av forråtnelse ved infeksjoner eller kreftsår. Den fylte hele hjemmet og maskerte alt annet. Mer vanlig var sammensatte luktkonstellasjoner, der lukt fra sykdom, kropp og manglende renhold i hjemmet inngikk i en ubestemmelig blanding:

«Og noen ganger når du åpner døra inn til leiligheten, så slår det mot deg et sammensurium av lukter, sår, urin, avføring, innestengt, matlukt og litt søppel som ligger rundt.»

Sykepleierne oppfattet at vond lukt i hjemmet var skambelagt uansett årsak. De oppfattet også at brukere med luktproblematikk i hjemmet var dobbelt så sårbare fordi luktene i hjemmet ikke bare berørte dem som personer, men også invaderte stedet deres. Både person og hjem risikerte å bli utsatt for andres avsky. Samtidig fremkalte de ubehagelige luktene kroppslige reaksjoner hos sykepleierne i form av grimaser, brekninger og vemmelse.

\section{«Sykepleierne oppfattet at vond lukt i hjemmet var skambelagt uansett årsak.»}

De manglet kunnskap om luktens fysiologi og fortolket reaksjonene, i tråd med en allmennkulturell forståelse, som uttrykk for avsky overfor brukerne og hjemmet. Det at sykepleierne reagerte slik, var i sterk konflikt med deres yrkesmoralske forpliktelse til å ivareta sårbare brukere. Denne konflikten skapte betydelige moralske kvaler og følelsen av å være uprofesjonell: 
«Av og til når du åpner kolostomien, så er det en intens lukt ... Og det var en katt som surret rundt bena. Og så kastet katten opp kattehår som den hadde spist ... Og det er den eneste gangen jeg måtte snu meg bort og brekke meg. Og pasienten ble forferdelig lei seg, og jeg ble forferdelig lei meg. For jeg tenker at det må være ille for den personen å se at jeg føler ubehag ved å stelle han. Og jeg tenker at jeg ikke var profesjonell lenger når jeg måtte brekke meg.»

\section{Strategier for lukthåndtering}

Sykepleierne begrunnet sitt handlingsvalg med et $\varnothing$ nske om å gi brukerne adekvat hjelp og beskytte dem og hjemmet mot andres avsky. De benyttet i hovedsak tre strategier:

Den ene strategien var å redusere eller fjerne luktene gjennom praktiske handlinger rettet mot sykdomsrelaterte årsaker, for eksempel gjennom sårog stomistell, eller hjelp til personlig hygiene. Det var mindre vanlig å fjerne det som luktet i omgivelsene fordi de oppfattet det som en utidig inngripen $\mathrm{i}$ brukernes hjem.

\section{«Munnbind ble sjelden brukt av frykt for at brukerne skulle bli støtt.»}

En annen strategi var å minimere luktinntrykk for ikke å reagere kroppslig. Sykepleierne benyttet ulike teknikker som å arbeide raskt, skape fysisk avstand i pleiesituasjonen, holde pusten eller puste gjennom munnen. Munnbind ble sjelden brukt av frykt for at brukerne skulle bli støtt. Det var også vanlig å fjerne seg mentalt ved å tenke på andre ting.

Teknikkene bidro til at sykepleierne ikke reagerte kroppslig, for eksempel med grimaser, brekning eller vemmelse. Observasjonene i hjemmet viste imidlertid at den sterke fokuseringen på å disiplinere kroppen $\mathrm{i}$ flere tilfeller medførte svekket observasjonsevne og redusert mental tilstedeværelse. 
En tredje strategi var taushet og bortforklaringer som «jeg kjenner ingen ting, det må du ikke tenke på» dersom brukeren selv kommenterte lukt. Sykepleierne mente det ville være krenkende å initiere en samtale om lukt. Det at de var i andres hjem, forsterket dette synspunktet:

«Jeg har aldri snakket med brukere om lukt ... Det er jo veldig krenkende for pasientene hvis vi snakker mye om det. Jeg føler da at pasientene tror vi ikke har lyst til å utføre den jobben vi gjør. Derfor pleier jeg ikke å ta opp det med lukten.»

«Og sånn som for vår del, så kommer vi hjem til folk. Vi er gjester $i$ andres hus. Vi kan ikke bare buse frem med lukt der.»

Sykepleierne fremhevet at manglende kunnskap om luktpersepsjon og fravær av et adekvat språk for vond lukt var viktige årsaker til tausheten deres. En uttrykte seg slik:

«Du kan si til en annen at 'i dag ser du dårlig ut', men du kan ikke si til en annen at 'du lukter vondt' med empati.»

\section{Brukernes vurdering av sykepleiernes handlingsvalg}

Brukernes erfaringer med og vurderinger av sykepleiernes handlingsstrategier varierte. Praktisk handling gjennom sikkert utførte prosedyrer og bruk av luktreduserende bandasjer og stomiutstyr ga brukerne trygghet. Frykten for lukt fra stomier, urinlekkasje og sår var stor. At utstyret satt tett og godt, reduserte angsten og førte til at de i større grad våget å delta i sosiale sammenhenger.

Flere uttrykte imidlertid en grunnleggende redsel for at det skulle lukte vondt i huset, og ikke bare av dem personlig. Brukerne hadde sjelden opplevd at sykepleiere fjernet mulige årsaker til vond lukt $\mathrm{i}$ omgivelsene. 


\section{Ble usikre av sykepleiernes taushet}

Brukerne hadde få erfaringer med og synspunkter på sykepleierens teknikker for å minimere luktinntrykk. De reflekterte imidlertid rundt situasjoner der de hadde sett sykepleiere reagere kroppslig. I et sårstell hadde en bruker opplevd at sykepleieren skar grimaser og vendte seg bort. Sykepleieren verken forklarte eller kommenterte reaksjonene. Det skapte usikkerhet i situasjonen og redsel i etterkant:

«For den redselen jeg har nå - åh! For eksempel: Det var en som satte seg ved siden av meg på trikken. Og så bare reiste han seg og satte seg et annet sted. Og da ble jeg helt sånn [viser forferdelse i ansiktet]: 'Hva er det? Er det lukt? Begynner jeg å lukte igjen?'»

Det var ikke de kroppslige reaksjonene i seg selv, men det at de ikke ble forklart, som skapte problemet. Taushet fra sykepleierne var den strategien brukerne hadde st $\varnothing$ rst innvendinger mot. De $\varnothing$ nsket gjennomgående større åpenhet. Ingen kunne huske at sykepleiere på eget initiativ hadde snakket med dem om luktproblematikk på en faglig måte, eller spurt om deres behov og $\varnothing$ nsker. Flere av brukerne sa at de kjente luktene selv. De oppfattet sykepleiernes bortforklaringer som respektløse:

«Nei, men du, nesten alle sykepleierne sier at de ikke kjenner noe ... Hvis jeg sier når de skifter på såret: 'Åh, uff nå kommer lukten', så sier de at de ikke kjenner så mye. Jeg vet ikke om det er for å trøste meg, jeg, eller? [Ler litt.].Hva med min erfaring, da? Er det ikke sant det jeg opplever?»

Brukerne beskrev videre sine egne lukterfaringer med sterke bilder: «Når jeg kjenner lukten, ser jeg for meg det grusomme som er meg», «lukten fra såret minner meg om likhuset» eller «jeg og hjemmet mitt lukter som råtten fisk». Alle brukte banneord når de snakket om luktproblematikk. 


\section{Diskusjon}

Hensikten med denne studien var å utforske hvordan sykepleiere erfarte og håndterte ubehagelig lukt i relasjon med brukere i hjemmet. Vi ville også unders $\varnothing$ ke hvordan brukerne erfarte sykepleiernes handlingsvalg.

Funnene viser at hjemmets lukter var varierte. De kunne være forårsaket av sykdom eller en blanding av sykdom, kroppslukt og uhygieniske forhold i omgivelsene. Blandingsluktene ble rapportert som mest vanlige. Det er få slike kontekstuelle luktbeskrivelser både fra hjemmesykepleie og institusjon. Det er derfor vanskelig å relatere funnene til annen forskning.

\section{«Hjem skal være rene og lukte godt og friskt.»}

Beskrivelsene er ikke vakre og bryter markant med sosiale og kulturelle normer for hvordan det skal lukte og se ut i hjemmet. Hjem skal være rene og lukte godt og friskt. Sosiokulturelle luktstudier viser at vond lukt fra person og hjem er assosiert med moralske vurderinger. Vellukt er forbundet med det gode og skjønne - ubehagelig lukt med det vonde, frastøtende og umoralske $(15,16)$. I studien til Waskul og Vannini blir vond lukt i hjemmet og fra personer beskrevet som lavstatus og sosialt ekskluderende (17).

\section{Taushet som beskyttelse mot skam}

Når sykepleierne oppfattet brukere som bor i illeluktende hjem, som dobbelt sårbare fordi både personen og hjemmet var utsatt for andres avsky, er det i tråd med allmennkulturelle vurderinger. Sykepleieforskeren Liaschenko betegner sårbarheten som berører både personen og vedkommendes sted, for «spatial vulnerability» (spatial = romlig, vulnerability = sårbarhet) (18). Det finnes ingen norsk oversettelse av selve begrepet, men det dekker godt sykepleiernes og brukernes erfaringer som er presentert i denne studien. 
Det var styrende for sykepleierens handlingsvalg å handle slik at brukerne og hjemmet ble beskyttet mot andres avsky. De fjernet luktene gjennom praktisk handling i taushet, uten å la seg merke kroppslig. Disse måtene å håndtere skam- og tabubelagte forhold på, er allmenne og konvensjonelle (19).

De inngår også i sykepleiens faglitteratur som anbefalinger for hvordan helsepersonell skal ut $\varnothing v e$ sitt faglige og moralske ansvar i pleiesituasjoner med kulturelt skam- og tabubelagte problemstillinger (20, 21). Praktisk handling koplet med kroppslig disiplin og verbal tilbakeholdenhet i møte med skambelagte kroppslige problemstillinger har lang tradisjon $\mathrm{i}$ sykepleie. A ha en indre fornemmelse for hva den andre trenger uten at brukeren må si noe, har vært beskrevet som et uttrykk for respekt, innlevelse og omsorg (20-22). Sykepleierne handlet slik sett i tråd med faglige anbefalinger.

\section{Brukerne ønsket åpenhet}

Brukernes erfaringer viste at sykepleiernes handlingsstrategier fungerte ulikt når det gjaldt å beskytte brukerne og hjemmet mot andres avsky. Praktisk handling i form av godt sår- og stomistell og hjelp til personlig hygiene var grunnleggende for at brukerne skulle føle seg trygge i møte med andre. Flere studier viser til liknende resultater $(3-5,23-25)$.

Vond lukt i hjemmet skyldtes også uhygieniske forhold og dårlig luft i omgivelsene. Brukerne ønsket at sykepleierne i større grad skulle snakke med dem om dette og komme med løsningsforslag. Sykepleierne var mer tilbakeholdne. De begrunnet valget ved å henvise til brukernes autonomi og at de var gjester $i$ andres hjem. 
Retten til selvbestemmelse i hjemmet er forankret i den vestlige kulturen (26-28) og gjenspeiler seg i lovverk (29) og sykepleiens verdigrunnlag (30). Vektleggingen av brukerens autonomi i lovverk og fagtradisjon kan bidra til å forklare sykepleiernes tilbakeholdenhet, men det er grunn til å spørre om deres moralsk begrunnete handlingsvalg forsterket brukernes sårbarhet $\mathrm{i}$ hjemmet med tanke på andres avsky.

\section{Strategier virket motsatt}

Strategien minimering av luktinntrykk bidro til at sykepleieren unngikk å reagere synlig på luktene, men den medførte svekket observasjonsevne og redusert tilstedeværelse. Nøyaktige observasjoner er grunnleggende for adekvat behandling, og tilstedeværelse er sentralt for å skape gode relasjoner (22). Det å disiplinere kroppen for å beskytte brukeren mot opplevelsen av skam og avsky kunne dermed redusere muligheten for behandling og for å utvikle velfungerende relasjoner.

\section{«Brukerne etterlyste gjennomgående større åpenhet.»}

Sykepleieren benyttet taushet og bortforklaringer for ikke å krenke brukerne og hjemmet. Brukererfaringene viste imidlertid at denne strategien fungerte motsatt. Tausheten forsterket skammen og ensomheten, svekket tilliten til egne erfaringer og reduserte muligheten for hjelp. Brukerne etterlyste gjennomgående større åpenhet.

Brukererfaringer og $\varnothing$ nsker om åpenhet ved luktproblematikk er lite systematisk tematisert i andre studier. Det er derfor vanskelig å vurdere hvordan våre funn relaterer seg til luktproblematikk i andre sammenhenger. Taushet kan forsterke skam og ensomhet og redusere muligheten for hjelp. Det er dokumentert ved andre kulturelt skam- og tabubelagte problemstillinger enn lukt, for eksempel psykisk sykdom, aids og overgrep $(31,32)$. 


\section{Tabu i språket}

En grunnleggende utfordring knyttet til åpenhet om vond lukt er språket, slik funnene i studien vår også viser. Årsakene er flere. Fremveksten av det moderne samfunnet med offentlige sanitærprosjekter har bidratt til å fjerne lukt av søppel, forråtnelse, urin og avføring fra det offentlige og henvist luktene til det private rom. Privatisering av denne typen lukter betyr at de i liten grad er en del av et kollektivt språkforråd, og de ordene som finnes for å beskrive dem, er negativt ladet. Det finnes heller ingen offentlig akseptert diskurs om hvordan man samtaler om det ekle og uestetiske $(2,33)$.

Denne tabuiseringen gjør det utfordrende for den som kommer utenfra, i denne sammenhengen sykepleieren, å tematisere luktproblematikk. Risikoen for å bruke ord som vil kunne oppfattes som respektløse og stigmatiserende, er betydelig. I slike situasjoner blir brukernes egne beskrivelser av luktene svært viktige. De gir innsikt i hvordan man kan språksette kulturelt tause skam- og tabubelagte problemstillinger på en meningsbærende måte. Det fordrer imidlertid at sykepleiere bryter tausheten og ettersp $\varnothing$ r brukernes erfaringer.

Språk er også relatert til kunnskap. Sykepleierne manglet grunnleggende kunnskap om luktpersepsjon, der reaksjoner på ubehagelig lukt kan forklares som autonome, fysiologiske reaksjoner på lukten, og ikke som uttrykk for avsky for personen $(34,35)$. Det er viktig med kunnskap om fysiologiske årsaksforklaringer. Den vil kunne bidra til å redusere skammen hos sykepleieren som reagerer, og opplevelsen av avsky hos den som utsettes for reaksjonene. Det kan gjøre det mulig med en mer åpen og ekte samhandling.

\section{Studiens begrensninger}


Utvalg av felter og informanter er for lite til å trekke noen generelle konklusjoner. Feltene har dessuten begrenset geografisk spredning. Det er mulig at sykepleierens sårbarhetsvurderinger og handlingsvalg hadde vært annerledes hvis vi hadde gjennomført studien i landbruksområder eller sterkt industrialiserte områder der ubehagelig lukt i større grad er en del av en offentlig luktkontekst enn i denne studien.

\section{Konklusjon og implikasjoner for praksis}

Studien gir et innblikk i hvor kompleks lukthåndtering er i hjemmet. Funnene indikerer at vond lukt i hjemmet gjør brukerne dobbelt så sårbare fordi både person og hjem er utsatt for andres avsky. Etablerte sykepleiefaglige handlingsvalg som praktisk handling, disiplinering av kroppen og taushet fungerte ulikt når det gjaldt å gi brukerne adekvat hjelp. De oppfattet praktisk handling som viktig, men utfordret tausheten og ønsket større åpenhet.

Manglende kunnskap om luktpersepsjon og fravær av et adekvat språk var sentrale årsaker til sykepleiernes taushet. Studien indikerer at det å styrke sykepleiernes kunnskapsgrunnlag om luktpersepsjon, etterspørre brukernes erfaring og samtale om lukterfaringer $\mathrm{i}$ kollegafellesskapet er viktig for kunne utvikle fullgode hjelpetilbud til brukere med luktproblematikk. Det er behov for ytterligere forskning innenfor dette feltet.

Vi takker Lovisenberg diakonale høgskole og Det medisinske fakultet, Universitetet $i$ Oslo for å ha finansiert og tilrettelagt studien.

\section{Referanser}

1. Isaksen LW. Om angsten for den andres avsky. Inkontinens som et sosialt og kulturelt fenomen. I: Wyller T, red. Skam: Perspektiver på skam og ære i det moderne. Bergen: Fagbokforlaget Vigmostad og Bjørke; 2001. 
2. Isaksen LW. Om lukten og skammen. En historie om kroppens uorden. I: Gressgård R, Meyer S, red. Fanden går i kloster: Elleve tekster om det andre. Oslo: Spartacus Forlag; 2002.

3. Lund-Nielsen B, Muller K, Adamsen L. Qualitative and quantitative evaluation of a new regimen for malignant wounds in women with advanced breast cancer. J Wound Care. 2005a;14(2):69-73.

4. Lund-Nielsen B, Muller K, Adamsen L. Malignant wounds in women with breast cancer: feminine and sexual perspectives. J Clin Nurs. 2005b;14(1):56-64.

5. Lindahl E. Striving for purity. Interviews with people with malodorous exuding ulcers and their nurses. Umeå: Umeå universitet; 2008.

6. Alexander SJ. An intense and unforgettable experience: the lived experience of malignant wounds from the perspectives of patients, caregivers and nurses. Int Wound J. 2010;7(6):456-65.

7. Lindahl E, Norberg A, Soderberg A. The meaning of living with malodorous exuding ulcers. $J$ Clin Nurs. 2007;16(3a):68-75.

8. Akhmetova A, Saliev T, Allan IU, Illsley MJ, Nurgozhin T, Mikhalovsky S. A comprehensive review of topical odor-controlling treatment options for chronic wounds. J Wound Ostomy Continence Nurs. 2016;43(6):598-609.

9. Wilkes LM, Boxer E, White K. The hidden side of nursing: why caring for patients with malignant malodorous wounds is so difficult. J Wound Care. 2003;12(2):76-80. 
10. Lindahl E, Norberg A, Soderberg A. The meaning of caring for people with malodorous exuding ulcers. Journal of Advanced Nursing. 2008;62(2):16371.

11. Aranda S. Silent voices, hidden practices: exploring undiscovered aspects of cancer nursing. Int $\mathrm{J}$ Palliat Nurs. 2001;7(4):178-85.

12. Breievne G. Lukt og lidelse: fortolkning og håndtering av ubehagelig lukt $\mathrm{i}$ hjemmesykepleie. Oslo: Institutt for helse og samfunn, Det medisinske fakultet, Universitetet i Oslo; 2014.

13. Fangen K. Deltagende observasjon. 2. utg. Bergen: Fagbokforlaget Vigmostad og Bjørke; 2010.

14. Malterud K. Kvalitative metoder i medisinsk forskning. En innføring. 3. utg. Oslo:

Universitetsforlaget; 2011.

15. Corbin A. The foul and the fragrant. Odor and the French social imagination. Cambridge/Massachusetts: Harvard University Press; 1986.

16. Classen C, Howes D, Synnot A. Aroma. The cultural history of smell. London / New York: Routledge; 1997.

17. Waskul DD, Vannini P. Smell, odor, and somatic work: Sense-making and sensory management. Social Psychology Quarterly. 2008;8(No. 1):53-71.

18. Liaschenko J. Ethics and the geography of the nurse-patient relationship: Spatial vulnerabilities and gendered space. Sch Inq Nurs Pract. 1997;11(1):45-59.

19. Goffman E. Interaction ritual: Essays in face to face behavior: Chicago: Aldine Transaction; 2005.

20. Lawler J. Bak skjermbrettene. Sykepleie, somologi og kroppslige problemer. Oslo: Gyldendal Norsk Forlag; 1996. 
21. Martinsen K. Løgstrup og sykepleien. Oslo:

Akribe; 2012.

22. Nightingale F. Notater om sykepleie. Samlede utgaver. Oslo: Universitetsforlaget; 1997.

23. McKenzie F, White CA, Kendall S, Finlayson A, Urquhart M, Williams I. Psychological impact of colostomy pouch change and disposal. Br J Nurs. 2006;15(6):308-16.

24. Getliffe K, Fader M, Cottenden A, Jamieson K, Green N. Absorbent products for incontinence: 'treatment effects' and impact on quality of life. J Clin Nurs. 2007;16(10):1936-45.

25. Kelechi TJ, Prentice M, Madisetti M, Brunette G, Mueller M. Palliative care in the management of pain, odor, and exudate in chronic wounds at the end of life: a cohort study. J Hosp Palliat Nurs. 2017;19(1):17-25.

26. Martinsen K. Huset og sangen, gråten og skammen. I: Wyller T, red. Skam: Perspektiver på skam, ære og skamløshet i det moderne. Bergen: Fagbokforlaget Vigmostad og Bjørke; 2001.

27. Angus J, Kontos P, Dyck I, McKeever P, Poland B. The personal significance of home: habitus and the experience of receiving long-term home care. Sociology of Health \& Illness. 2005;27(2):161-87.

28. Molony SL. The Meaning of Home. A qualitative metasynthesis. Research in Gerontological Nursing. 2010;3(4):291-307.

29. Forskrift 27. juni 2003 nr. 792 om kvalitet i pleie- og omsorgstjenestene for tjenestetyting etter lov av 19. november $1982 \mathrm{nr} .66$ om helsetjenesten i kommunene og etter lov av 13. desember $1991 \mathrm{nr} .81 \mathrm{om}$ sosiale tjenester $\mathrm{m}$. v. Tilgjengelig fra: https://lovdata.no/dokument/SF/forskrift/2003-06-27792 (nedlastet 21.02.2018). 
30. Oresland S, Maatta S, Norberg A, Jorgensen MW, Lutzen K. Nurses as guests or professionals in home health care. Nurs Ethics. 2008;15(3):371-83.

31. Zerubavel E. The elephant in the room: Silence and denial in everyday life. Oxford: Oxford University Press; 2006.

32. Lauveng A. Unyttig som en rose. Oslo:

Cappelen; 2006.

33. Skårderud F. Prestens løgn. Vårt Land; 2013.

34. Hawkes CH, Doty RL. The neurology of olfaction. Cambridge: Cambridge University Press; 2009.

35. Rouby C, Bensafi M. Is there a hedonic dimension to odors? I: Rouby C, Schaal B, Dubois D, Gervaris R, Holley A, red. Olfaction, taste and cognition. Cambridge: Cambridge University press; 2005. s. 14059 . 